Vincent, J. M. \& Waters, L. M. (1953). J. gen. Microbiol. 9, 357-370.

\title{
The Influence of the Host on Competition amongst Glover Root-nodule Bacteria
}

\author{
By J. M. VINCENT aNd L. M. WATERS \\ Agricultural Microbiology Laboratory, Faculty of Agriculture, \\ University of Sydney, N.S.W., Australia
}

SUMMARY: Serological typing has been used to study competition between five strains of Rhizobium trifolii in growth and nodulation with four species of host. Although a proportion of non-reacting antigenic variants appears to have been encountered, the serological method remains uniquely suitable for studies of this kind.

Irrespective of host species or level of inoculum the population of bacteria in the tube of seedling agar approached a maximum of approximately $4 \times 10^{6}$ viable cells per $\mathrm{ml}$. No consistent relationship was found between host species and the proportion of the several strains of rhizobia in the population outside the plant. The relative frequency of strains was, however, markedly affected by level of total inoculum and time of growth after inoculation. Some strains grew better at first but reached a lower maximum than others which fared better at higher population levels, whether from a heavier inoculum or prolonged growth. The population on the root surface itself failed to reflect any marked host influence in the balance between strains.

The proportions of strains found in the nodules were unrelated to their representation in the root's external environment. Each host exercised a specific selective effect in this regard.

Factors which determine the balance between strains of root-nodule bacteria (Rhizobium species) that are in competition with each other for growth and nodulation are likely to be of considerable practical and theoretical significance. Nitrogen fixation by a legume growing in a soil containing parasitic rhizobia will depend on the ability of an effective strain to compete with the ineffective bacteria. This will be true whether the effective strain is introduced as inoculum or is already part of the local bacterial flora. This aspect of the legume symbiosis is also interesting from an ecological point of view. The technique of serological typing opens up possibilities for investigating the effect of host species on the competitive balance between rhizobial strains. This account deals with our experience with four species of clover, each associated with five strains of clover nodule bacteria (Rh. trifolii).

\section{METHODS}

Hosts. Trifolium pratense L. (red clover), T. incarnatum L. (crimson clover), T. repens $\mathbf{L}$. (white clover) and $T$. subterraneum $L$. (subterranean clover). All seed has been surface sterilized with ethanol and $0 \cdot 2 \%(\mathrm{w} / \mathrm{v})$ mercuric chloride and washed with several changes of sterile water. All uninoculated controls remained free of nodules. 
Growth medium. Nitrogen-free seedling agar of the following composition $(\%, w / v): \mathrm{CaHPO}_{4}, 0.1 ; \mathrm{K}_{2} \mathrm{HPO}_{4}, 0.02 ; \mathrm{MgSO}_{4} .7 \mathrm{H}_{2} \mathrm{O}, 0.02 ; \mathrm{NaCl}, 0.02$; $\mathrm{FeCl}_{3}, 0.01$; agar 0.8 ; pH adjusted to $\mathrm{pH} 6.5$ with $\mathrm{NaOH} ; 10 \mathrm{ml}$. agar deeps in $6 \times \frac{3}{4}$ in. test tubes.

Organisms. The source and nitrogen-fixing ability of each strain is given in Table 1. They were all serologically distinguishable.

Table 1. Details of bacterial strains

\begin{tabular}{|c|c|c|c|c|c|}
\hline \multirow[b]{2}{*}{$\begin{array}{l}\text { Collection } \\
\text { number }\end{array}$} & \multirow[b]{2}{*}{ Source } & \multicolumn{4}{|c|}{ Effectiveness* with } \\
\hline & & T. pratense & T. repens & $\begin{array}{l}\text { T. incar- } \\
\text { natum }\end{array}$ & $\begin{array}{l}T \text {. subter- } \\
\text { raneum }\end{array}$ \\
\hline $\begin{array}{r}36 \\
157 \\
204\end{array}$ & $\begin{array}{l}T . \text { repens } \\
T . \text { repens } \\
T \text {. repens (culture } \\
\text { collection)t }\end{array}$ & $\begin{array}{l}e \\
\mathbf{E}\end{array}$ & $\begin{array}{l}\mathbf{E} \\
\mathbf{E} \\
\mathbf{E}\end{array}$ & $\begin{array}{l}\mathbf{E} \\
\mathbf{I} \\
\mathbf{I}\end{array}$ & $\begin{array}{l}\mathbf{E} \\
\mathbf{I} \\
\mathbf{I}\end{array}$ \\
\hline $\begin{array}{l}284 \\
297\end{array}$ & $\begin{array}{l}\text { T. glomeratum } \\
\text { T. incarnatum }\end{array}$ & $\underset{i}{i}$ & $\underset{\mathbf{E}}{\mathbf{E}}$ & $\underset{\mathbf{E}}{\mathbf{E}}$ & $\underset{\mathbf{E}}{\mathbf{E}}$ \\
\hline
\end{tabular}

* Grading based on several tests: $\mathrm{E}$, highly effective; $I$, markedly ineffective; $e$ and $i$ are corresponding intermediate states.

$\dagger$ 'Clover F' clone from Dr H. G. Thornton, F.R.S., Rothamsted.

Setting up the test. Surface-sterilized seeds were allowed to germinate for 2 days in a sterile Petri dish, and well-developed seedlings planted singly in each tube of agar medium; $0.25 \mathrm{ml}$. mixed and diluted suspension of the five bacterial strains was added immediately to each tube.

Four levels of inocula were used: $\mathbf{M}_{1}, \mathbf{M}_{2}, \mathbf{M}_{3}$ and $\mathbf{M}_{4}$ of increasing tenfold concentration. Viable counts of the suspensions used in the preparation of inocula permitted the number of each strain to be determined. The numbers for $M_{1}$ (per tube of $10 \mathrm{ml}$. agar) are given below:

\begin{tabular}{|c|c|}
\hline Strain & $\begin{array}{l}\text { No. of } \\
\text { viable cells }\end{array}$ \\
\hline $\begin{array}{r}\mathbf{3 6} \\
\mathbf{1 5 7} \\
\mathbf{2 0 4} \\
\mathbf{2 8 4} \\
\mathbf{2 9 7}\end{array}$ & $\begin{array}{l}20 \\
30 \\
70 \\
20 \\
20\end{array}$ \\
\hline & 160 \\
\hline
\end{tabular}

Number of rhizobia in the root's external environment. The whole contents of the tube was shaken vigorously 25 times with $100 \mathrm{ml}$. sterile water to give a first dilution, c. 1/10. Subsequent dilutions and plate counts were set up in the usual way.

Estimation of proportion of each strain in the external environment. Twenty separated colonies conforming to the characteristics of rhizobium, but otherwise taken randomly, were picked separately to yeast mannitol agar slopes and the growth typed by testing a suspension (made up in $0.9 \%$ saline and heated at $100^{\circ}$ for $30 \mathrm{~min}$. to destroy the less specific flagellar antigens) against the range of sera at dilution 1/100. Control suspensions without serum were set up at the same time to detect unstable antigen.

Typing-nodule isolates. Six-week-old plants were removed aseptically from the agar and rinsed in sterile water, so that the suspensions could be used to 
estimate the proportions of the various strains in the root environment at that stage. The whole root surface was then sterilized with ethanol and $0 \cdot 1 \%(w / v)$ $\mathrm{HgCl}_{2}$ for $2 \mathrm{~min}$., washed in six changes of sterile water, and the contents of separate nodules streaked on plates of yeast mannitol agar. As far as possible, ten nodules were taken from each plant, the position of each relative to the crown of the plant having been recorded. The culture for serological typing was then developed from a characteristic and well-separated colony.

Presentation of results. Original data are given in full. In considering the results it is more convenient to express the proportions of each strain as a percentage of the total, but $\chi^{2}$ tests, on which conclusions as to significance have been based, have all been calculated on actual numbers.

\section{RESULTS}

Total viable population at 3 and 10 days

Table 2 gives the logarithms of viable counts for duplicate tubes of each treatment. Generation time and total growth at 10 days are little, if at all, affected by the species of host. The former is consistently shorter for the earlier time interval and at the lower inoculum levels. By 10 days all treatments have reached approximately the same level: $40 \times 10^{6}$ per tube. The lowest inoculum $\left(M_{1}\right)$ reached this level by 12 days, the only occasion of testing.

\section{Ratio of strains in the tube population}

The full data are set out in Tables 3 and 4.

The large proportion of isolates that fail to react with any of the testing sera calls for some comment. A plant test gave nodulation with all but one out of twenty-two such cultures from 3-day material. They cannot, therefore, be dismissed as non-rhizobial contaminants. Moreover, re-isolates from these nodules were all identified as one or other of several of the strains in these proportions: strain 36,1 ; strain 157,2 ; strain 204, 5; strain 284, 13. The application of this ratio to the total 3-day negative reactors appears reasonable. Whether it can be applied to the more numerous 10-day negative reactors is more doubtful, and data will be considered with and without this adjustment.

Agreement between duplicate tubes. It will be seen from Table 3 that there is fair to good agreement between the contents of duplicate tubes. The distribution of culture types, including the unstable and negative cultures, was tested by $\chi^{2}$ for each pair of duplicate tubes. This gave twenty-four series of $\chi^{2}$ each with 6 D.F. Only one of the series ( 3 days, $M_{3}$, white clover) gave a significant difference between duplicate tubes $\left(\chi^{2}=16.1 ; P=0.02-0.01\right)$. The remaining $\chi^{2}$ ranged from $2 \cdot 2$ to $12 \cdot 2$ ( $P$ from 0.9 to $\left.0 \cdot 10-0 \cdot 05\right)$. Total $\chi^{2}$ (144 D.F.) was $166 \cdot 8(P=0 \cdot 2-0 \cdot 1)$.

The variation between duplicate tubes for strain 157 , using all comparisons available in Table 3 , with minor adjustments to bring all cases to the basis of a total of 20 per tube, gave a standard deviation for each tube of $\pm 2 \cdot 0$.

Remaining calculations have been based on the totals of duplicate tubes except in the subsidiary test with inoculum $M_{1}$ (Table 4) where duplicates were not available. 


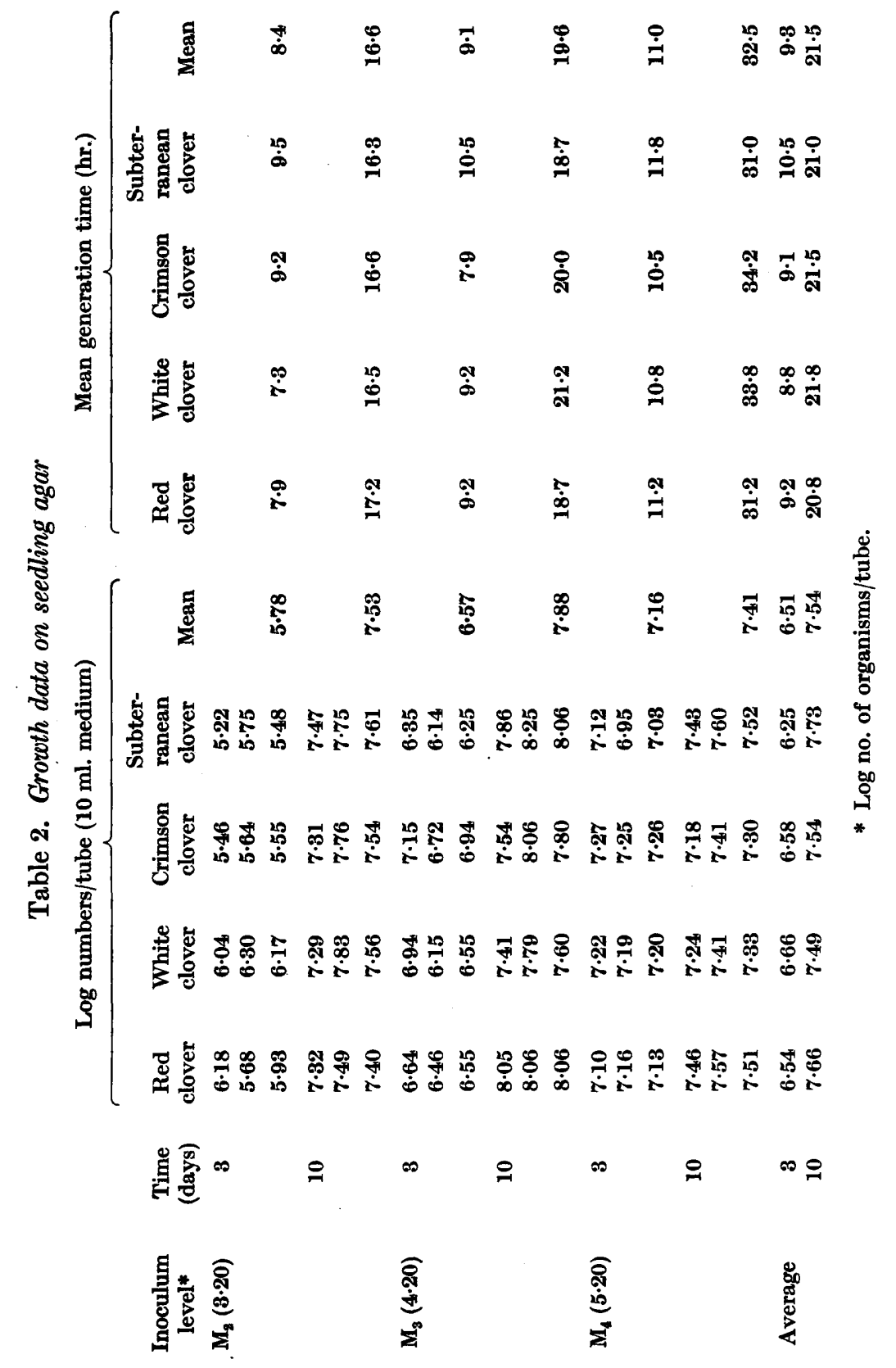




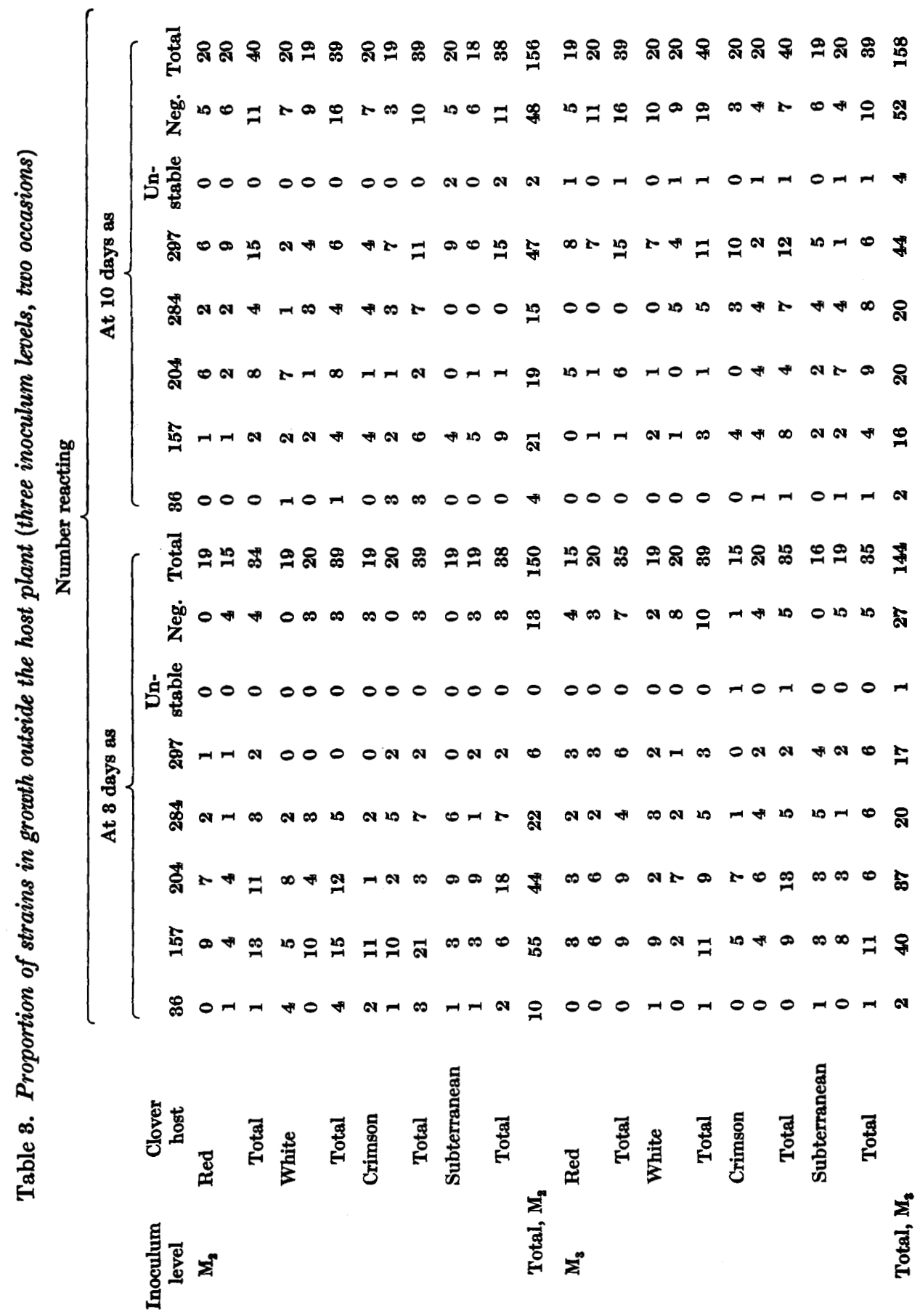




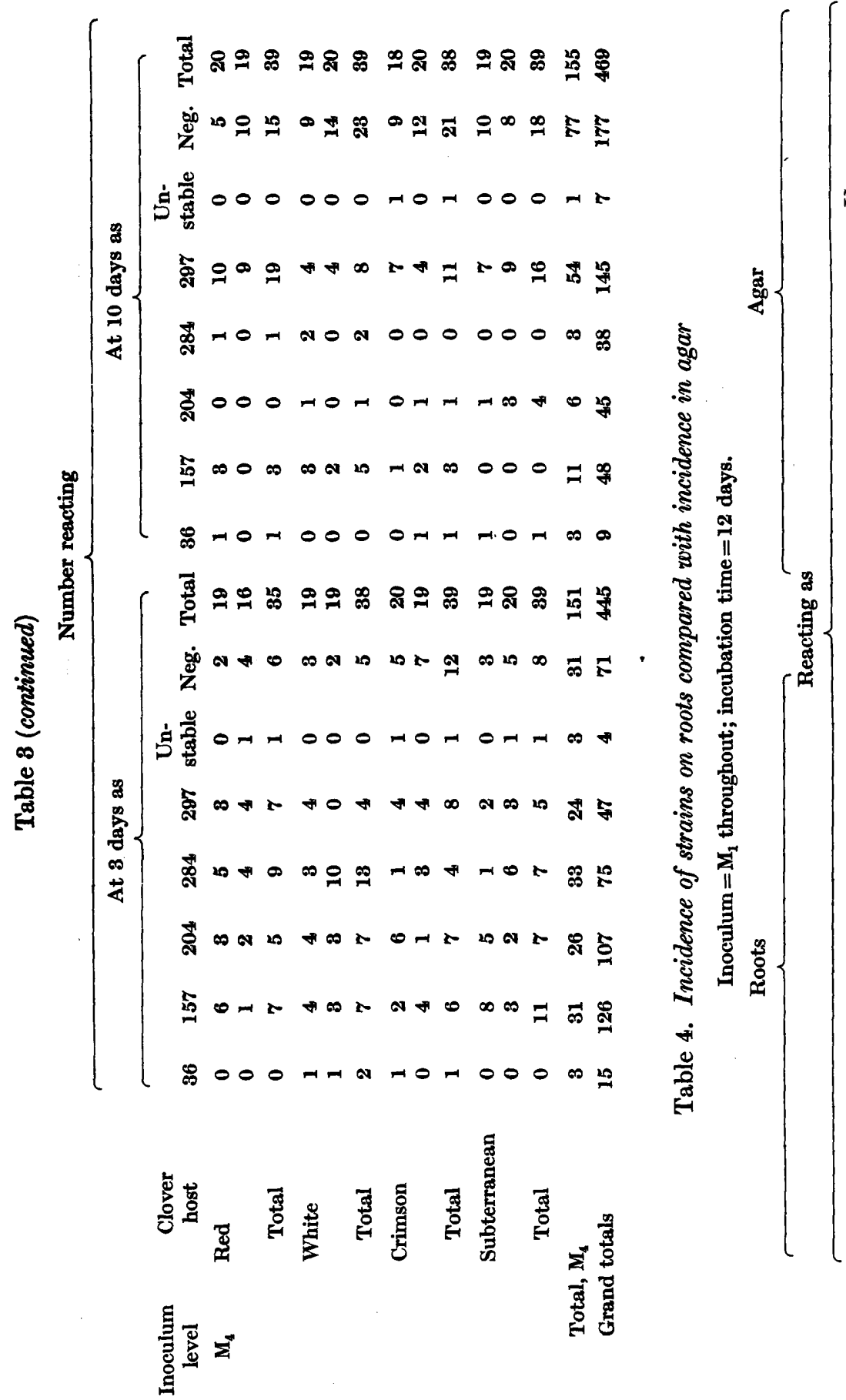

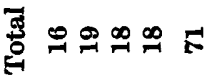

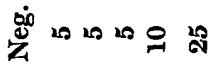

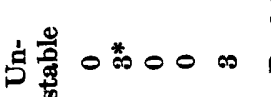

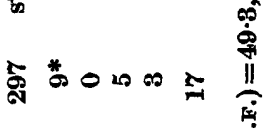

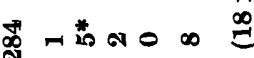
茟 0 N 一满。需 O O

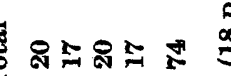
क 艺 N N

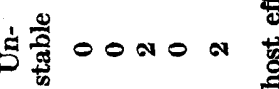

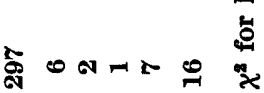

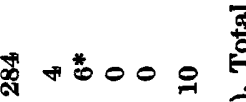

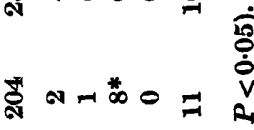
ถ⿻ ஜ 0 -

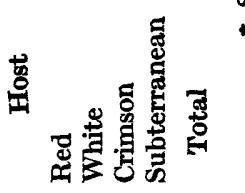


Influence of the host. The data have been analysed for possible host effect on the six occasions represented by inocula $M_{2}, M_{3}$ and $M_{4}$, each at 3 and 10 days.
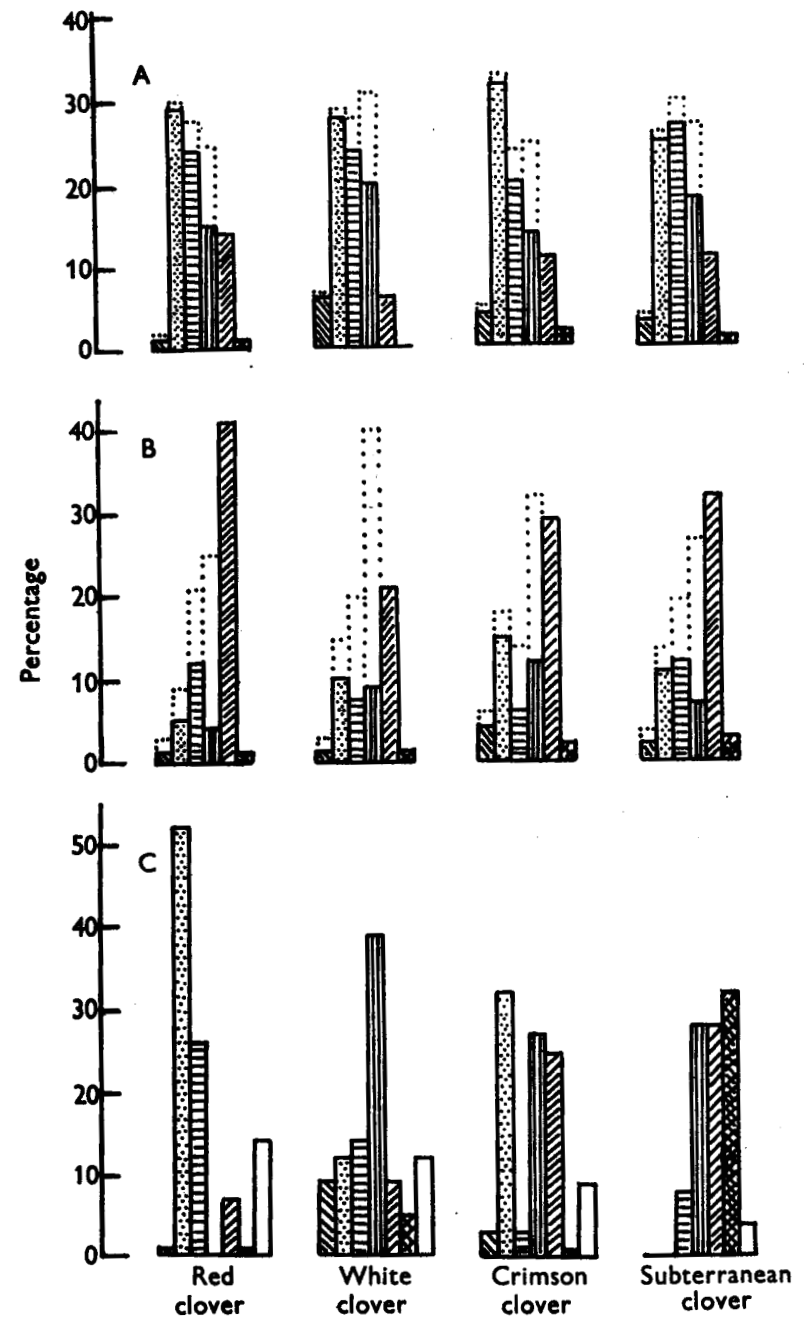

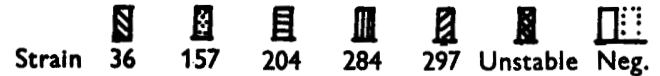

Fig. 1. Proportion of strains according to host. A, outside host, 3 days;

$B$, outside host, 10 days; $C$, from nodules.

In each case the proportions of strains for each host has been compared with the average for the four hosts:

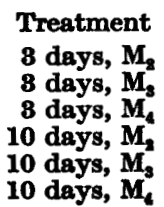

$\chi^{2}(\mathbf{1 8}$ D.F. $)$
$\mathbf{3 8 \cdot 5}$
$\mathbf{1 6} \cdot \mathbf{7}$
$\mathbf{1 6 \cdot 2}$
$\mathbf{3 3 \cdot 9}$
$\mathbf{3 3 \cdot 8}$
$\mathbf{2 1 \cdot 1}$

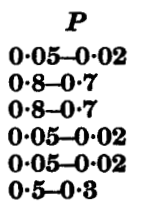


Although in three of the six cases the $\chi^{2}$ test is significant, there are no marked trends due to host. (Fig. 1A, B). Noting the results in more detail:

(a) Red clover: deficiency of strain $284, M_{3}$ at 10 days.

(b) White clover: no significant excess or deficiency.

(c) Crimson clover: excess 36 (10 days, $M_{2}$ ) and 157 (10 days, $M_{3}$ ), each on one occasion.

(d) Subterranean clover: excess 204, deficiency 157, each on one occasion (3 days, $M_{2}$ ).

Strain $\mathbf{3 6}$ is generally a minor constituent, but the other four have fair representation at one stage or another.

An analysis of the frequency of occurrence of strain 157 failed to show any host effect (F, 3/24: 1.7, P>0.05).

Proportion of strains in the immediate root environment. A subsidiary test (inoculum $M_{1}, 12$ days) was made to determine whether the population closest to the root showed any greater host effect than the growth elsewhere in the seedling agar (Table 4). Although in this smaller test there were significant departures from random distribution, this was no more marked in the root than in the agar population. The proportions of strains on the roots and in the agar, based on the totals for all hosts, were not different $(P=0 \cdot 2-0 \cdot 1)$. In more detail this was the result with each host:

(a) Red clover: excess 297 (agar).

(b) White clover: excess 157 and 284 (plant and agar); deficiency of strain 297 (agar).

(c) Crimson clover: excess 204 (plant).

(d) Subterranean clover: no significant excess or deficiency.

Comparison of these results with those for inocula $\mathbf{M}_{2}-\mathbf{M}_{4}$ emphasizes the absence of any trend associated with a particular host.

Strain 36 occurred in this set of tubes more frequently than with the other inocula levels.

Colonies obtained from the rhizosphere when the plants were harvested at 6 weeks also failed to show any marked host influence:

\begin{tabular}{|c|c|c|c|c|c|c|c|c|}
\hline \multirow[b]{2}{*}{ Clover host } & \multicolumn{5}{|c|}{ Percentage due to strain } & \multirow{2}{*}{$\begin{array}{c}\text { Unstable } \\
\text { antigen }\end{array}$} & \multirow[b]{2}{*}{ Neg. } & \multirow{2}{*}{$\begin{array}{l}\text { Total } \\
\text { cases }\end{array}$} \\
\hline & $\mathbf{3 6}$ & 157 & 204 & 284 & 297 & & & \\
\hline $\begin{array}{l}\text { Red } \\
\text { White } \\
\text { Crimson } \\
\text { Subterranean }\end{array}$ & $\begin{array}{l}\mathbf{9} \\
\mathbf{0} \\
\mathbf{0} \\
\mathbf{0}\end{array}$ & $\begin{array}{r}3 \\
15 \\
13 \\
12\end{array}$ & $\begin{array}{l}18 \\
30 \\
30 \\
24\end{array}$ & $\begin{array}{r}18 \\
15 \\
26 \\
9\end{array}$ & $\begin{array}{l}\mathbf{2 8} \\
\mathbf{2 2} \\
\mathbf{2 0} \\
\mathbf{2 7}\end{array}$ & $\begin{array}{l}\mathbf{9} \\
\mathbf{0} \\
\mathbf{6} \\
\mathbf{0}\end{array}$ & $\begin{array}{r}15 \\
18 \\
5 \\
28\end{array}$ & $\begin{array}{l}\mathbf{3 3} \\
\mathbf{2 7} \\
\mathbf{5 4} \\
\mathbf{3 3}\end{array}$ \\
\hline Total, 6 weeks & 2 & 11 & 26 & 18 & 24 & 4 & 15 & 147 \\
\hline Total, 10 days & $\mathbf{2}$ & 10 & 10 & 8 & 31 & 2 & 37 & 469 \\
\hline
\end{tabular}

$x^{2}, 6$ weeks material, distribution of strains as a function of host (18 D.F. $)=27 \cdot 4$ $(P=0 \cdot 10-0 \cdot 05)$. No individual cases were significant.

Stage of growth. Strains 157 and 204 were well represented in the 3-day population but were largely replaced by strain 297 at 10 days (compare 
Figs. $1 \mathrm{~A}$ and $1 \mathrm{~B}, 2 \mathrm{~A}$ and $2 \mathrm{~B}$ ). The changes in proportion of strains are highly significant for each inoculum level:

$\begin{array}{ccc}\text { Inoculum } & \chi^{2}(6 \mathrm{D.F}) & \boldsymbol{P} \\ \mathrm{M}_{2} & \mathbf{5 7 . 9} & <0.00 \\ \mathrm{M}_{3} & \mathbf{3 5 . 8} & <0.00 \\ \mathrm{M}_{4} & \mathbf{7 7 . 8} & <0.00\end{array}$
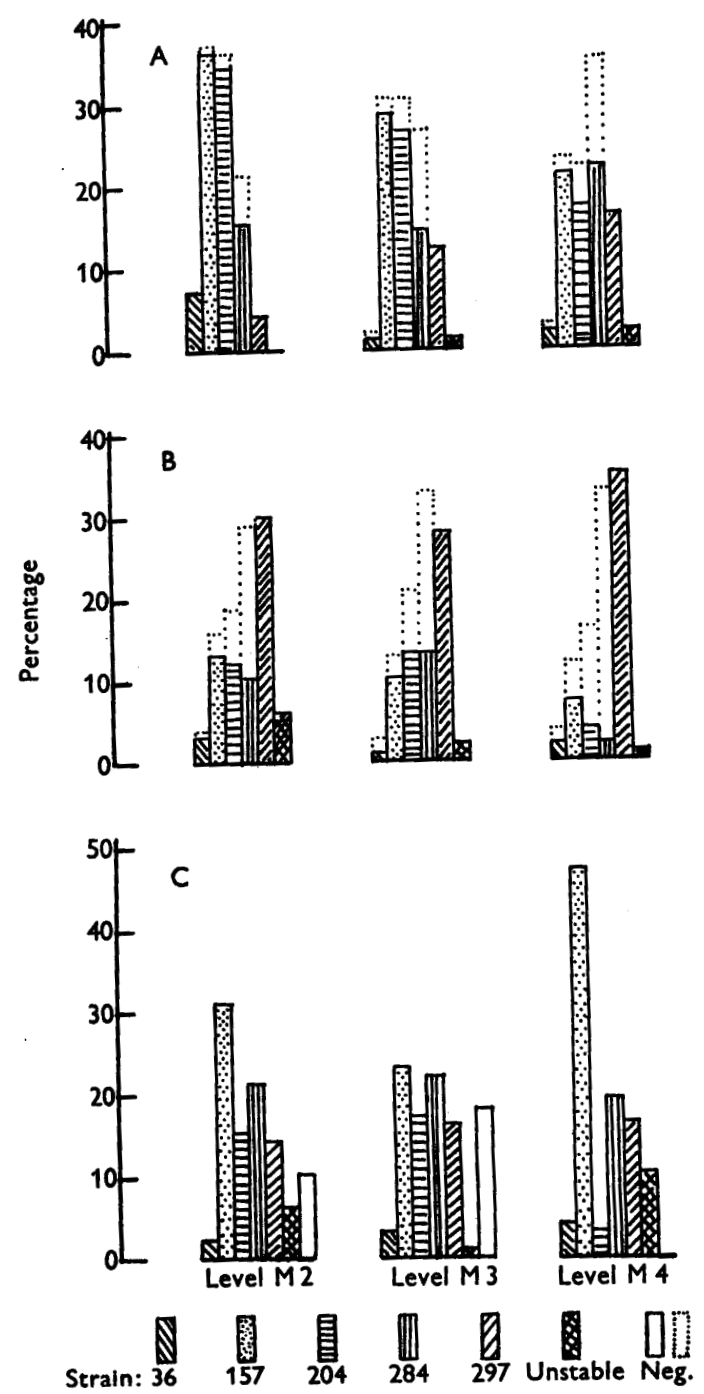

Fig. 2. Proportion of strains according to inoculum level. A, outside host, 3 days; $B$, outside host, 10 days; $C$, from nodules.

Similarly, the analysis of strain 157 showed a highly significant change in proportion of the strain with time $(F, 1 / 24=35 \cdot 6, P<0.01)$.

Comparing the 10-day with the 6-week result above, strains 204 and 284 were more common on the later occasion, negative reactors less frequent. $\chi^{2}(6$ D.F. $)=51 \cdot 2, P<0.001$. 
Infiuence of inoculum level. There is a definite shift in the relative proportion of strains according to the size of the inoculum (Fig. 2A, B). This is most marked at 3 days (Fig. 2A), but can be seen in the 10-day result as well (Fig. 2B). These results are statistically highly significant:

$\begin{array}{ccc}\text { Stage of growth } & \chi^{2} \text { (12 D.F.) } & P \\ 8 \text { days } & 42.6 & <0.001 \\ 10 \text { days } & \mathbf{3 2 . 6} & 0.01-0.001\end{array}$

The analysis of strain 157 showed a significant change with inoculum level (F, 2/24=4.8; $P=0.05-0.01)$.

\section{Ratio of strains in the nodules}

Full data for the several inocula levels are set out in Table 5. The agreement between replicate tubes is probably as good as could be expected for the necessarily small numbers per tube. A $\chi^{2}$ test has been applied to the distribution of culture types for cases having replicates. In no case was there any significant difference between replicates. Total $\chi^{2}(132$ D.F.) was 120.0, $P>0.9$. The standard deviation of strain 157, based on the replicate tubes in the $\mathbf{M}_{2}$ data was $\pm 1 \cdot 4$. Totals of replicates are utilized in subsequent comparisons.

Influence of the host. Percentages for the separate hosts (inoculum levels pooled) are plotted in Fig. 1C. Unlike the cultures obtained from the growth outside the root, the proportion of the several strains found in the nodules is markedly affected by the host species. Considering the distribution of strains for the four hosts at each inoculum level:

$\begin{array}{ccc}\text { Inoculum } & \chi^{\mathbf{2}}(\mathbf{1 8} \text { D.F.) } & P \\ M_{\mathbf{2}_{2}} & \mathbf{6 5 . 5} & <0.001 \\ \mathbf{M}_{\mathrm{2}} & \mathbf{3 6 . 9} & \mathbf{0 . 0 1 - 0 . 0 0 1} \\ \mathbf{M}_{4} & \mathbf{4 8 . 7} & <0.001 \\ \text { All (Fig. 1C) } & \mathbf{1 4 3 . 4} & <0.001\end{array}$

The analysis of 157 obtained from the plants of the $M_{2}$ tubes for which several replicates were available showed a highly significant host effect (F, 3/8 $=13.5, P<0.01$ ).

Influence of inoculum level. On the other hand, the proportion of strains for the one host is largely independent of inoculum concentration. Taking the data for each host separately, there was a significant inoculum effect in the case of white clover but this is almost entirely due to the results in a single tube with inoculum $\mathbf{M}_{4}$ :

\begin{tabular}{|c|c|c|}
\hline Clover host & $\chi^{2}$ (12 D.F.) & $\boldsymbol{P}$ \\
\hline $\begin{array}{l}\text { Red } \\
\text { White }\end{array}$ & $\begin{array}{l}13 \cdot 4 \\
\mathbf{3 3 \cdot 5}\end{array}$ & $\begin{array}{l}0.5-0.3 \\
0.01\end{array}$ \\
\hline Crimson & $9 \cdot 0$ & 0.7 \\
\hline Subterranean & $15 \cdot 4$ & $0.3-0.2$ \\
\hline All hosts (Fig. 2C) & $24 \cdot 7$ & $0 \cdot 05-0 \cdot 0$ \\
\hline
\end{tabular}

The variant tube with white clover had a larger proportion of strain 157 and less 284 than for the three inocula generally. The results with all hosts are significant, but this is due to some excess of 157 and deficiency of 204 and non-reactors in inoculum $M_{4}$. No real trends can be detected in these results. 
Table 5. Proportion of strains in nodules

\begin{tabular}{|c|c|c|c|c|c|c|c|c|c|}
\hline \multirow[b]{2}{*}{$\begin{array}{c}\text { Inoculum } \\
\text { level }\end{array}$} & \multirow[b]{2}{*}{$\begin{array}{c}\text { Clover } \\
\text { host }\end{array}$} & \multicolumn{8}{|c|}{ Reacting as } \\
\hline & & 36 & 157 & 204 & 284 & 297 & $\begin{array}{c}\text { Un- } \\
\text { stable }\end{array}$ & Neg. & Total \\
\hline $\mathbf{M}_{2}$ & Red & $\begin{array}{l}\mathbf{0} \\
\mathbf{0} \\
\mathbf{0}\end{array}$ & $\begin{array}{l}7 \\
8 \\
4\end{array}$ & $\begin{array}{l}\mathbf{3} \\
\mathbf{1} \\
\mathbf{6}\end{array}$ & $\begin{array}{l}\mathbf{0} \\
\mathbf{0} \\
\mathbf{0}\end{array}$ & $\begin{array}{l}\mathbf{0} \\
\mathbf{0} \\
\mathbf{0}\end{array}$ & $\begin{array}{l}0 \\
1 \\
0\end{array}$ & $\begin{array}{l}\mathbf{0} \\
\mathbf{0} \\
\mathbf{0}\end{array}$ & $\begin{array}{l}10 \\
10 \\
10\end{array}$ \\
\hline & Total & $\mathbf{0}$ & 19 & 10 & 0 & 0 & 1 & $\mathbf{0}$ & $\mathbf{3 0}$ \\
\hline & White & $\begin{array}{l}1 \\
\mathbf{0} \\
\mathbf{1}\end{array}$ & $\begin{array}{l}\mathbf{0} \\
\mathbf{1} \\
\mathbf{0}\end{array}$ & $\begin{array}{l}\mathbf{0} \\
\mathbf{2} \\
\mathbf{1}\end{array}$ & $\begin{array}{l}6 \\
0 \\
4\end{array}$ & $\begin{array}{l}\mathbf{0} \\
\mathbf{3} \\
\mathbf{1}\end{array}$ & $\begin{array}{l}1 \\
1 \\
0\end{array}$ & $\begin{array}{l}1 \\
1 \\
1\end{array}$ & $\begin{array}{l}\mathbf{9} \\
\mathbf{8} \\
\mathbf{8}\end{array}$ \\
\hline & Total & 2 & 1 & $\mathbf{3}$ & 10 & 4 & 2 & 3 & 25 \\
\hline & Crimson & $\begin{array}{l}\mathbf{0} \\
\mathbf{0} \\
\mathbf{0}\end{array}$ & $\begin{array}{l}\mathbf{5} \\
\mathbf{2} \\
\mathbf{2}\end{array}$ & $\begin{array}{l}\mathbf{0} \\
\mathbf{0} \\
\mathbf{1}\end{array}$ & $\begin{array}{l}1 \\
2 \\
1\end{array}$ & $\begin{array}{l}\mathbf{3} \\
\mathbf{2} \\
\mathbf{4}\end{array}$ & $\begin{array}{l}\mathbf{1} \\
\mathbf{0} \\
\mathbf{0}\end{array}$ & $\begin{array}{l}\mathbf{0} \\
\mathbf{1} \\
\mathbf{2}\end{array}$ & $\begin{array}{r}10 \\
7 \\
10\end{array}$ \\
\hline & Total & 0 & 9 & 1 & 4 & 9 & 1 & $\mathbf{B}$ & 27 \\
\hline & Subterranean & $\begin{array}{l}\mathbf{0} \\
\mathbf{0} \\
\mathbf{0}\end{array}$ & $\begin{array}{l}\mathbf{0} \\
\mathbf{0} \\
\mathbf{0}\end{array}$ & $\begin{array}{l}\mathbf{0} \\
\mathbf{1} \\
\mathbf{0}\end{array}$ & $\begin{array}{l}\mathbf{3} \\
\mathbf{2} \\
\mathbf{2}\end{array}$ & $\begin{array}{l}\mathbf{0} \\
\mathbf{1} \\
\mathbf{0}\end{array}$ & $\begin{array}{l}\mathbf{0} \\
\mathbf{2} \\
\mathbf{1}\end{array}$ & $\begin{array}{l}\mathbf{0} \\
\mathbf{0} \\
\mathbf{0}\end{array}$ & $\begin{array}{l}\mathbf{3} \\
\mathbf{6} \\
\mathbf{3}\end{array}$ \\
\hline & Total & 0 & $\mathbf{0}$ & 1 & 7 & $\mathbf{1}$ & 3 & $\mathbf{0}$ & 12 \\
\hline & Total $\mathbf{M}_{\mathbf{2}}$ & 2 & 29 & 15 & 21 & 14 & 7 & 6 & 94 \\
\hline $\mathbf{M}_{\mathbf{3}}$ & Red & $\begin{array}{l}\mathbf{0} \\
\mathbf{0} \\
\mathbf{0}\end{array}$ & $\begin{array}{l}\mathbf{3} \\
\mathbf{4} \\
6\end{array}$ & $\begin{array}{l}4 \\
4 \\
1\end{array}$ & $\begin{array}{l}\mathbf{0} \\
\mathbf{0} \\
\mathbf{0}\end{array}$ & $\begin{array}{l}\mathbf{3} \\
\mathbf{0} \\
\mathbf{2}\end{array}$ & $\begin{array}{l}\mathbf{0} \\
\mathbf{0} \\
\mathbf{0}\end{array}$ & $\begin{array}{l}\mathbf{0} \\
\mathbf{2} \\
\mathbf{0}\end{array}$ & $\begin{array}{r}10 \\
10 \\
9\end{array}$ \\
\hline & Total & $\mathbf{0}$ & 13 & $\boldsymbol{\theta}$ & $\mathbf{0}$ & 5 & $\mathbf{0}$ & 2 & 29 \\
\hline & White & $\begin{array}{l}\mathbf{0} \\
\mathbf{0} \\
\mathbf{1} \\
\mathbf{0}\end{array}$ & $\begin{array}{l}\mathbf{1} \\
\mathbf{0} \\
\mathbf{0} \\
\mathbf{0}\end{array}$ & $\begin{array}{l}\mathbf{0} \\
\mathbf{2} \\
\mathbf{0} \\
\mathbf{2}\end{array}$ & $\begin{array}{l}5 \\
1 \\
5 \\
0\end{array}$ & $\begin{array}{l}\mathbf{0} \\
0 \\
0 \\
1\end{array}$ & $\begin{array}{l}\mathbf{0} \\
\mathbf{0} \\
\mathbf{0} \\
\mathbf{0}\end{array}$ & $\begin{array}{l}\mathbf{0} \\
\mathbf{2} \\
\mathbf{1} \\
\mathbf{1}\end{array}$ & $\begin{array}{l}\mathbf{6} \\
\mathbf{5} \\
\mathbf{7} \\
\mathbf{4}\end{array}$ \\
\hline & Total & 1 & $\mathbf{1}$ & 4 & 11 & 1 & $\mathbf{0}$ & 4 & 22 \\
\hline & Crimson & $\begin{array}{l}\mathbf{0} \\
\mathbf{0} \\
\mathbf{2}\end{array}$ & $\begin{array}{l}2 \\
4 \\
1\end{array}$ & $\begin{array}{l}\mathbf{0} \\
\mathbf{0} \\
\mathbf{1}\end{array}$ & $\begin{array}{l}0 \\
4 \\
4\end{array}$ & $\begin{array}{l}5 \\
1 \\
1\end{array}$ & $\begin{array}{l}\mathbf{0} \\
\mathbf{0} \\
\mathbf{0}\end{array}$ & $\begin{array}{l}1 \\
1 \\
1\end{array}$ & $\begin{array}{r}8 \\
10 \\
10\end{array}$ \\
\hline & Total & 2 & 7 & 1 & 8 & 7 & o & 3 & 28 \\
\hline & Subterranean & $\mathbf{0}$ & $\mathbf{0}$ & 1 & 0 & $\mathbf{1}$ & $\mathbf{1}$ & 1 & 4 \\
\hline & Total, $\mathbf{M}_{3}$ & $\mathbf{3}$ & 21 & 15 & 19 & 14 & 1 & 10 & 83 \\
\hline $\mathbf{M}_{\mathbf{4}}$ & Red & $\mathbf{0}$ & 9 & 1 & 0 & 0 & 0 & 0 & 10 \\
\hline & White & 2 & 5 & 1 & 1 & o & 1 & o & 10 \\
\hline & Crimson & $\begin{array}{l}\mathbf{0} \\
\mathbf{0}\end{array}$ & $\begin{array}{l}4 \\
4\end{array}$ & $\begin{array}{l}\mathbf{0} \\
\mathbf{0}\end{array}$ & $\begin{array}{l}\mathbf{3} \\
\mathbf{5}\end{array}$ & $\begin{array}{l}\mathbf{3} \\
\mathbf{0}\end{array}$ & $\begin{array}{l}\mathbf{0} \\
\mathbf{0}\end{array}$ & $\begin{array}{l}\mathbf{0} \\
\mathbf{0}\end{array}$ & $\begin{array}{r}10 \\
9\end{array}$ \\
\hline & Total & $\mathbf{0}$ & 8 & $\mathbf{0}$ & 8 & $\mathbf{3}$ & 0 & $\mathbf{0}$ & 19 \\
\hline & Subterranean & $\begin{array}{l}\mathbf{0} \\
\mathbf{0}\end{array}$ & $\begin{array}{l}\mathbf{0} \\
\mathbf{0}\end{array}$ & $\begin{array}{l}\mathbf{0} \\
\mathbf{0}\end{array}$ & $\begin{array}{l}\mathbf{0} \\
\mathbf{0}\end{array}$ & $\begin{array}{l}\mathbf{2} \\
\mathbf{3}\end{array}$ & $\begin{array}{l}3 \\
1\end{array}$ & $\begin{array}{l}\mathbf{0} \\
\mathbf{0}\end{array}$ & $\begin{array}{l}5 \\
4\end{array}$ \\
\hline & Total & $\mathbf{0}$ & 0 & o & o & 5 & 4 & 0 & 9 \\
\hline & Total, $M_{4}$ & 2 & 22 & 2 & $\mathbf{9}$ & 8 & $\mathbf{5}$ & $\mathbf{0}$ & 48 \\
\hline $\mathbf{M}_{1}$ & Red & $\mathbf{0}$ & 6 & $\mathbf{3}$ & o & $\mathbf{1}$ & $\mathbf{0}$ & $\mathbf{0}$ & 10 \\
\hline & Subterranean & $\begin{array}{l}\mathbf{0} \\
\mathbf{0} \\
\mathbf{0} \\
\mathbf{1} \\
\mathbf{0} \\
\mathbf{0}\end{array}$ & $\begin{array}{l}\mathbf{0} \\
\mathbf{0} \\
\mathbf{0} \\
\mathbf{1} \\
\mathbf{1} \\
\mathbf{0}\end{array}$ & $\begin{array}{l}\mathbf{0} \\
\mathbf{2} \\
\mathbf{0} \\
\mathbf{1} \\
\mathbf{0} \\
\mathbf{0}\end{array}$ & $\begin{array}{l}\mathbf{0} \\
\mathbf{3} \\
\mathbf{0} \\
\mathbf{0} \\
\mathbf{0} \\
\mathbf{0}\end{array}$ & $\begin{array}{l}\mathbf{4} \\
\mathbf{0} \\
\mathbf{3} \\
\mathbf{0} \\
\mathbf{0} \\
\mathbf{2}\end{array}$ & $\begin{array}{l}\mathbf{0} \\
\mathbf{0} \\
\mathbf{0} \\
\mathbf{0} \\
\mathbf{0} \\
\mathbf{0}\end{array}$ & $\begin{array}{l}0 \\
0 \\
0 \\
4 \\
1 \\
2\end{array}$ & $\begin{array}{l}\mathbf{4} \\
\mathbf{5} \\
\mathbf{3} \\
\mathbf{7} \\
\mathbf{2} \\
\mathbf{4}\end{array}$ \\
\hline & Total & 1 & 2 & 3 & $\mathbf{3}$ & 9 & $\mathbf{0}$ & 7 & 25 \\
\hline & Total, $\mathbf{M}_{1}$ & 1 & 8 & 6 & 3 & 10 & $\mathbf{0}$ & 7 & 85 \\
\hline
\end{tabular}


Negative reactors again require some consideration. In cases which were first negative, duplicate cultures picked from the same plates were in many cases positive to one of the testing sera. The ratio of strains represented by these cases was practically the same as the ratio for strains positive on the first occasion. This fact, and the relatively small proportion of negative reactors amongst nodule isolates, seems to indicate that such non-reactors would not seriously interfere with the estimate of strain proportions based on the positive cases.

The saline unstable controls, so common with subterranean clover (Fig. 1C), are more difficult. However, even if on this account subterranean clover were excluded, the selective effect of the host plant would be apparent with the other three species.

Relationship between proportion of strains outside the root and in the nodules

It is clear from the data already given that, under the conditions of this experiment, where several strains have been able to grow together in the root environment, success in forming nodules need have little to do with their relative growth outside the root. This will be seen: (i) by comparing the major influence exerted by the four hosts on the strains producing nodules (Fig. 1 C) with their insignificant effect on the population outside the plant (Fig. 1 A, B); (ii) by observing the failure of increasing inoculum concentrations to produce in nodules the same trends (decreasing 157, increasing 297) which are so marked amongst the corresponding populations outside the plant (Fig. 2C, cf. $A$ and $B$ ).

Moreover, examination of the relative position of each nodule on the root failed to show any relationship between this and the strain responsible for the nodule. There was, for example, no tendency for strain 157 , which grew so well at first, to be relatively more represented amongst the early formed nodules, nor for strain 297 , which largely dominated the late population, to be better represented amongst the younger nodules.

\section{DISCUSSION}

The performance of strains in the nodulation of each host can be set out in decreasing order:

$\begin{array}{ccc}\text { Red clover } & \text { White clover } & \begin{array}{c}\text { Crimson } \\ \text { clover }\end{array} \\ 157(\mathrm{E}) & 284(\mathrm{E}) & 157(\mathrm{I}) \\ 204(\mathrm{E}) & & 284(\mathrm{E}) \\ & & 297(\mathrm{E}) \\ 297(i) & 204(\mathrm{E}) & 36(\mathrm{E}) \\ 36(e) & 157(\mathrm{E}) & 204(\mathrm{I}) \\ 284(i) & 36(\mathrm{E}) & \\ & 297(\mathrm{E}) & \end{array}$

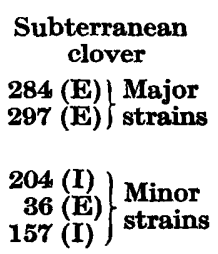

(Note: (E), etc., refers to known nitrogen-fixing effectiveness with the host concerned; see Table 1 for detail.)

Other data collected in this laboratory $(157>204,157>284$, for red clover; 204 $>157$ for subterranean clover) have been in agreement with these findings. 
At first glance one might be tempted to see some significance in the general occurrence of highly effective associates amongst those best able to produce nodules competitively. Strain 157 with crimson clover is, however, a striking exception which, taken with the fact that more effective than ineffective associations were involved amongst the host + bacterium pairings, is adequate warning against any generalization in this regard from the present data.

The evidence that competitiveness in nodule formation need not have any relationship to the relative vigour of growth outside the plant fails to support the generality of the conclusions reached by Nicol \& Thornton (1942) based on the few instances they were able to study with the means then at their disposal. The conclusion that the nature of the host can so clearly determine relative success in nodulation amongst strains without reference to their relative number in the plant's immediately external environment opens up the interesting question as to the stage in the invasion process at which this selectivity operates: at the point of root hair invasion or by determining survival and growth of cells that have gained entry?

The fact that more than one serological type has not been isolated from the same nodule under conditions such that different nodules on the one plant were commonly inhabited by different strains (Hughes \& Vincent, 1942) is perhaps relevant. It does not, however, provide any basis for a firm decision in favour of either of the possibilities noted above.

Relative infectivity of the strain on each of the hosts, so far as it can be assessed by earliness of nodulation and the number of nodules formed, provides at the best only a partial explanation of the host specificity reported in this paper. Unpublished data, obtained by Bockman in this laboratory by testing each strain against each host in single culture, relate both criteria reasonably well to nodulation competitiveness in the case of red clover. With the other three hosts, however, the evidence is either inconclusive or contradictory.

On the practical side, knowledge of host preferences might materially assist in the better selection of inocula for field use. This could be important in competition between inoculum and an established parasitic rhizobial population. It might also provide a solution to the difficulties associated with the simultaneous sowing of inoculated seed of two or several clover species, for which it is often difficult to find the one strain equally effective in nitrogen fixation. Strains could be chosen such that those effective for a particular host would also dominate that host's nodulation. On the present data, for example, a mixed sowing of red and subterranean clovers could be inoculated with a mixture of strains 157 (for red) and 297 (for subterranean). On the other hand, the use of mixed inocula without knowledge of host preferences would be quite irrational.

The position of negative reactors remains a somewhat unsatisfactory feature of the test. Their effect on the total result can be detected and allowed for in experiments of this kind because all isolations are expected to react with one or other of the test sera. In field tests, on the other hand, where failure to react with the test sera is taken as evidence of 'native' rhizobia, the uncertainty introduced by this phenomenon is more serious. One cause of trouble, 
apparently due to a heat-labile 'Vi-like' antigen capable of interfering with the somatic reaction, has been detected (Vincent, 1953). This can be avoided by the use of heated antigen and does not explain the negative cases in the present tests, all of which are based on material treated in this way. It seems that despite the high degree of serological stability that has been a feature of our experience with regularly maintained stock cultures (Purchase, Vincent \& Ward, 1951) experiments involving frequent single colony re-isolations, with or without intervening plant passage, give a proportion of cultures which fail to react with the homologous antiserum (i.e. that prepared against the original stock culture). The incidence of non-reacting 'variants' seems to vary with strains, as in our present experience with strain 284, but occurs commonly enough amongst others, as indicated by the fact that negative reactors have been found in four of the five strains involved in this work. The subsequent recovery of specific reacting strains from plants inoculated with a culture in a non-reacting state suggests a fairly readily reversed variation.

More work yet remains to be done on the serology of the rhizobia, but in the meanwhile the method remains undoubtedly the best experimental tool available for detailed studies of interaction between strains of rhizobia in various environments and for field studies on success with legume inoculation.

We are pleased to acknowledge the technical assistance rendered by Miss $W$. Fountain and the financial assistance of the University Research Fund, the Commonwealth Bank Rural Credits Fund and the Richmond River Pasture Improvement Committee.

\section{REFERENCES}

Hughas, D. Q. \& Vincent, J. M. (1942). Serological studies of the root-nodule bacteria. III. Tests of neighbouring strains of the same species. Proc. Linn. Soc. N.S.W. 67, 142.

Nrcol, H. \& Thornton, H. G. (1942). Competition between related strains of nodule bacteria and its influence on infection of the legume host. Proc. Roy. Soc. B, $130,32$.

Purchase, H. F., Vincent, J. M. \& Ward, L. M. (1951). Serological studies of the root-nodule bacteria. IV. Further analysis of isolates from Trifolium and Medicago. Proc. Linn. Soc. N.S.W. 76, 1.

Vincent, J. M. (1953). Vi-like antigen in clover nodule bacteria. Aust. J. Sci. 15, 133.

(Received 8 April 1953) 